\title{
Virulence of Puccinia triticina on Wheat in Nebraska during 1997 and 1998
}

\author{
J. E. Watkins, Professor, J. Schimelfenig, Research Technologist, Department of Plant Pathology, P. S. Baenziger, \\ Professor, Department of Agronomy, and K. M. Eskridge, Professor, Department of Biometry, University of Ne- \\ braska, Lincoln 68583-0722
}

\begin{abstract}
Watkins, J. E., Schimelfenig, J., Baenziger, P. S., and Eskridge, K. M. 2001. Virulence of Puccinia triticina on wheat in Nebraska during 1997 and 1998. Plant Dis. 85:159-164.

Urediniospore isolates of Puccinia triticina were obtained from wheat leaf collections made in three wheat-growing regions in Nebraska in 1997 and in four regions in 1998. Using 16 Thatcher lines that are near-isogenic for leaf rust resistance, 17 virulence phenotypes were found among 121 single uredinial isolates in 1997, and 42 virulence phenotypes were found among 178 isolates in 1998. The most prevalent phenotype in 1997 was MDRR (virulent on $\mathrm{Lr} 1,3,3 \mathrm{ka}, 10,11,18,23,24$, and 30). In 1998, virulence phenotypes MDRR and MDRM (virulent on $L r 1,3,3 \mathrm{ka}, 10,11,23,24$, and 30) were the most prevalent. In both years, virulence frequency was above $80 \%$ to genes $L r 1,3,3 \mathrm{ka}, 10,11,23,24$, and 30 and below $21 \%$ to $L r 2 a$, 17, and 26. Virulence frequency to $L r 2 c$ was $37 \%$ in 1997 and $22 \%$ in 1998 . No virulence was found to $\operatorname{Lr} 9,16$, or 21 in either year. New virulence phenotypes were detected in 1998 that were not found in 1997. In 1998, virulence was less frequent on $L r 2 a, 2 c, 3 k a, 18,24$, and 26 and more frequent on $\operatorname{Lr} 17$ than in 1997.
\end{abstract}

Additional keywords: near-isogenic lines, wheat leaf rust

Leaf rust, caused by Puccinia triticina Eriks. (2), occurs annually throughout most wheat (Triticum aestivum L.) growing regions of North America. Estimated wheat yield losses to leaf rust in the United States were $4.8,0.7,2.4,0.8,2.8$, and $1.6 \%$ in 1993, 1994, 1995, 1996, 1997, and 1998, respectively (D. L. Long, unpublished). During these years, estimated losses in Nebraska ranged from a low of $0.5 \%$ in 1994 and 1996 to a high of $4.0 \%$ in 1993 (J. E. Watkins, unpublished). In 1997 and 1998 , losses in Nebraska were estimated at 1.0 and $1.5 \%$, respectively. Value of the 1997 and 1998 Nebraska wheat crops was estimated at 400 million dollars annually.

Johnson and Mains (4) and Mains and Jackson (10) were the first to report the physiological specialization of $P$. triticina. They initially used the wheat cultivars Kanred and Malakof to separate $P$. triticina isolates, and then later used a series of 11 cultivars to differentiate physiological

Corresponding author: J. E. Watkins

E-mail: jwatkins1@unl.edu

Research support provided by the Nebraska Wheat Board and the University of Nebraska Agricultural Research Division Project NEB21-069. This paper is published as Journal Series No. 13000 by the Agricultural Research Division, Institute of Agriculture and Natural Resources, University of Nebraska-Lincoln.

Accepted for publication 16 October 2000.

Publication no. D-2000-1117-01R

(C) 2001 The American Phytopathological Society races. Their differential series was later reduced to eight cultivars (Malakof, $L r l$; Webster, Lr2a; Carina, $L r 2 b$; Brevit, $L r 2 c$ and $L r B$; Loros, $L r 2 c$; Mediterranean, $L r 3 a$; Democrat, Lr3a; and Hussar, Lr11) $(3,4,10,12)$. This set was further reduced to Malakof, Webster, Loros, Democrat, and Hussan, and virulence phenotypes of $P$. triticina, based on those five remaining genes, were classified into Unified $\mathrm{Nu}-$ meration (UN) races (8). Currently, the identification of virulence phenotypes is based on infection types expressed on seedlings of Thatcher wheat lines that are near-isogenic for 12 different leaf rust resistance genes (8).

Surveys on the physiological specialization of wheat pathogens have been used to estimate the relative prevalence and distribution of pathotypes, to monitor the spread of new virulence phenotypes and the loss of previously virulent phenotypes, and to identify which resistance genes are ineffective (7-9,16). Most wheat-producing countries undertake some kind of pathogen surveys to document physiological specialization. In North America, physiological specialization of $P$. triticina has been well documented through surveys in Canada (7), Mexico (17), and the United States (9). In the Great Plains $(11,13,18,20,21)$ and in the Pacific Northwest (15), the virulence frequency to leaf rust resistance genes has been monitored through periodic surveys in Minnesota, Nebraska, North Dakota, Oregon, Texas, and Washington. These surveys provide information needed in breeding for leaf rust resistance.
In the Great Plains, frequency of virulence to specific host genes often reflects the frequency prevalence of resistance genes used in commercial wheat cultivars. The selection pressure applied by the leaf rust resistance genes in commonly grown wheat cultivars plays an important role in determining shifts in virulence to these genes within the $P$. triticina population. Kolmer (5) reported that the virulence frequencies to $L r l, 2 a$, and $2 c$ in the prairie provinces of Canada during 1956 to 1987 increased with the increased incorporation of these genes into commercial wheat cultivars grown in North Dakota. Kolmer (7) attributed an increase in the virulence frequency to Lr16 from $5.9 \%$ in 1996 to $16.3 \%$ in 1997 to the production of several Canadian spring wheat cultivars having this gene. McVey and Long (14) speculated that the hard red winter wheat cultivar Arapahoe contains Lr16. In 1997 and 1998, this cultivar was grown on approximately $30 \%$ of the total wheat acreage in $\mathrm{Ne}$ braska. This gene continues to be used as a major source of leaf rust resistance in the Nebraska breeding program and is most likely carried by, in addition to Arapahoe, the cultivars Brule, Redland, Vista (14), and Millennium.

Shifts in the physiological specialization of $P$. triticina were detected in wheat leaf rust virulence surveys conducted in $\mathrm{Ne}$ braska since 1992. In 1992 and 1993, TFHvirulence phenotype group comprised the highest percentage of the total number of $P$. triticina isolates identified (20). Virulence phenotype groups MBR, MDR, and TDR predominated in 1995, with TFH comprising less than $1 \%$ of the isolates (20). The 1996 virulence survey found virulence phenotype groups MBR, MDR, TBR, and TBT comprised approximately $55 \%$ of the isolates identified. Not only did these surveys detect shifts in the prevalence of certain virulence phenotypes, but they also detected changes in the total number of virulence phenotypes in each of the survey years. Thirty-seven virulence phenotypes were identified in 1992, compared with 46, 20, and 18 in 1993, 1995, and 1996, respectively $(20,21)$. This indicates that the regional virulence phenotype and virulence frequency patterns in the central Great Plains constantly shift.

Objectives of the annual $P$. triticina virulence survey in Nebraska were to characterize the virulence of $P$. triticina populations in Nebraska in 1997 and 1998 and 
to compare these results with those of previous Nebraska surveys.

\section{MATERIALS AND METHODS}

Uredinial collections of $P$. triticina were made during June of 1997 and 1998 from farm fields and wheat nurseries. Surveys were conducted in the four major wheatgrowing regions of Nebraska (Fig. 1). The four regions differ in environmental characteristics, planting time, and to a lesser extent, in the cultivars grown. Elevation ranges from approximately $250 \mathrm{~m}$ in the east to $1,800 \mathrm{~m}$ in the Panhandle, and average annual precipitation varies from $76 \mathrm{~cm}$ in the east to $38 \mathrm{~cm}$ in the Panhandle. Winter wheat is generally planted 1 to 15 September in the Nebraska Panhandle, 15 to 25 September in the west central, 15 September to 1 October in the central, and 20 September to 1 November in the east. Winter wheat in the east is often planted in October into soybean residue. In 1997 and 1998, the hard red winter wheat cultivars Alliance, Arapahoe, Buckskin, Centura, Karl/Karl 92, Niobrara, and Vista comprised approximately $70 \%$ of the Nebraska winter wheat acreage.

Due to dry conditions in 1997 , leaf rust was not found in the Nebraska Panhandle. Collections of leaf rust were made approximately every 20 to $40 \mathrm{~km}$ or at the first field thereafter along a predetermined route from east to west through selected wheat-growing regions. The total number of samples collected varied in each region.

A sample collection consisted of leaves bearing uredinia from each of five to 10 plants per field. Fields were sampled by haphazardly selecting plants at approximately $10-\mathrm{m}$ intervals. Uredinia-bearing leaves were placed in glycine bags and stored in a cooler on ice until transported to the laboratory in the Department of Plant Pathology, University of NebraskaLincoln. In the laboratory, they were transferred to plastic bags and stored at $3{ }^{\circ} \mathrm{C}$ for 1 to 8 weeks. Urediniospores from each sample collection were then increased on 7- to 8-day-old Thatcher (CI 10003). Inoculated plants were set in a darkened dew

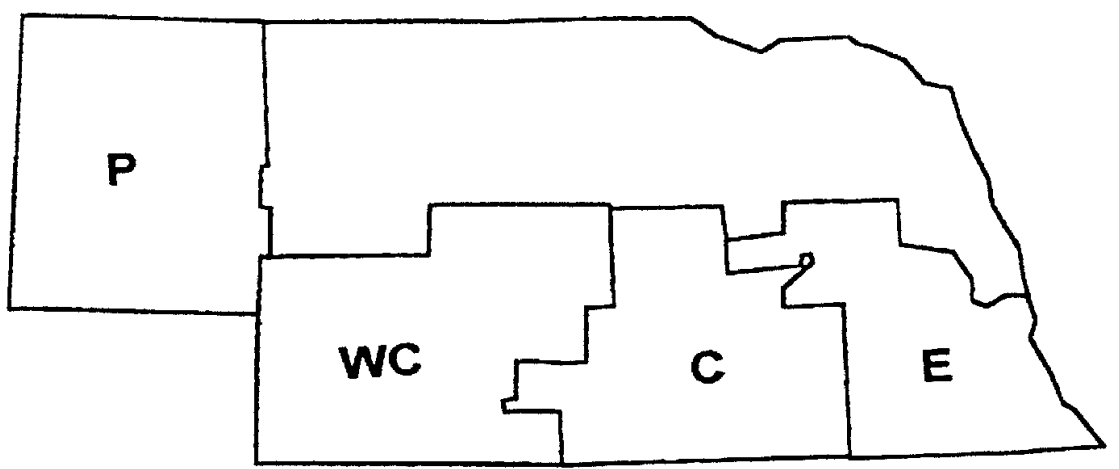

Fig. 1. Geographic regions surveyed for leaf rust (Puccinia triticina) on wheat (Triticum aestivum) in Nebraska during 1997 and 1998 growing seasons: $\mathrm{P}=$ Panhandle, $\mathrm{WC}=$ west central, $\mathrm{C}=$ central, and $\mathrm{E}=$ east. chamber at $98 \%$ relative humidity at $22^{\circ} \mathrm{C}$ for 18 to $24 \mathrm{~h}$. The plants were then placed in a greenhouse where daily temperature varied between 20 and $25^{\circ} \mathrm{C}$. Natural daylight in the greenhouse was supplemented with $400-\mathrm{W}$ metal halide lights providing a 14-h photoperiod.

Ten to 12 days after inoculation, a cyclone spore collector was used to collect urediniospores separately from one or two uredinia per collection into a size 00 gelatin capsule. Each single-uredinial isolate was immediately increased through one uredinial generation by inoculating onto leaves of Thatcher. During this increase procedure, the inoculated plants were isolated from each other in the greenhouse to prevent mixing isolates. After 10 to 12 days, urediniospores from each isolate increase were collected with the cyclone spore collector into size 00 gelatin capsules and dried in a desiccator for $24 \mathrm{~h}$. Each gelatin capsule was placed in a freezer vial and stored in a $-80^{\circ} \mathrm{C}$ freezer until inoculation onto the differential host set containing different leaf rust resistance genes.

Two single-uredinial isolates per sample collection in 1997 and one single-uredinial isolate per sample collection in 1998 were evaluated for virulence phenotype. Prior to inoculation of the near-isogenic differential set and supplemental lines, the urediniospore-containing gelatin capsules were removed from the $-80^{\circ} \mathrm{C}$ freezer and warmed at $40^{\circ} \mathrm{C}$ for $2 \mathrm{~h}$. Soltrol light industrial oil $(400 \mu \mathrm{l})$ was added to $4 \mathrm{mg}$ of urediniospores from each isolate. The urediniospore-oil suspension was atomized lings of a differential host set $(L r 1,2 a, 2 c$, $3,3 \mathrm{ka}, 9,11,16,17,24,26$, and 30) consisting of 12 near-isogenic lines of Thatcher, each with a different resistance gene (8). Supplemental near-isogenic host lines containing resistance genes $\operatorname{Lr} 10,18$, 21 , or 23 were also inoculated at the same time as the differential set. Each virulence phenotype data set consisted of 10 to 12 plants of each of the 16 near-isogenic lines. As previously described, inoculated plants were set in a darkened dew chamber for 18 onto the primary leaves of 7-day-old seed- to $24 \mathrm{~h}$ and then transferred to the greenhouse.

After 11 to 13 days, infection types on 10 to 12 leaves of each near-isogenic line were recorded as either low (; 1 , or 2$)$ or high (3 or 4). Each single-uredinial isolate was assigned a three-letter virulence phenotype code ( $P t$ code) based on high or low infection type on the 12 differentials, according to the $P t$ nomenclature established by the North American Leaf Rust Workers Committee in 1986 (8). Avirulence or virulence on $\operatorname{Lr} 10,18,21$, and 23 was indicated by adding a fourth letter to the $P t$ virulence code. Assessment of virulence phenotype was repeated for $10 \%$ of the single-uredinial isolates as a check on accuracy of reading the differential and supplemental lines for infection type.

To evaluate the trends of the virulence frequencies by year (1995, 1996, 1997, 1998) and over geographic region for 1997 and 1998, each of the near-isogenic lines was analyzed using weighted regression where the response variable was the presence or absence of virulence (19). Since weighted regression is adversely affected by a large number of cells with small counts, near-isogenic lines were not statistically analyzed if more than $25 \%$ of the cells had small counts. For the lines that were analyzed, a small value (0.5) was added to all cells to avoid computation problems due to small cell counts (1).

\section{RESULTS AND DISCUSSION}

Occurrence. In 1997, leaf rust was first observed in southeastern Nebraska in late May. Low night temperatures in the central Great Plains during late May slowed leaf rust development. By late June, leaf rust was widespread in eastern, south central, and west central Nebraska. Those cultivars with the highest levels of leaf rust infection were Karl 92, Ike, Scout 66, Alliance, and TAM 107. The virulence frequency in 1997 was high on Lr3, 10, and 11. Genes $L r 3,10$, and 11 are presumed to be in Karl 92 and 10 in Scout 66 (D. Long, personal communication, Proceedings of the 21st Hard Wheat Workers Workshop, Jan. 2830, 1998, Denver, CO).

Virulence phenotypes. During this 2year study, 299 single-uredinial isolates collected in Nebraska were characterized for virulence phenotype. Seventeen virulence phenotypes were identified in 1997 (Table 1) and 42 in 1998 (Table 2). Virulence phenotypes are arranged in Tables 1 and 2 by $P t$ code (8), and results are presented as numbers and percentages of isolates from each Nebraska wheat-producing region. The $\mathrm{M}$ - virulence phenotype groups (virulent on $\mathrm{Lrl}$ and 3) comprised 63\% of the isolates characterized in 1997 (Table 1). The most common virulence phenotype, MDRR, comprised $51 \%$ of total isolates characterized that year. This represented an increase in the prevalence of the MDR- phenotype from that found in the 
1995 and 1996 Nebraska surveys in which MDR accounted for only 21.6 and $9.7 \%$, respectively (21). It also differed from the results of the 1997 Canadian survey in which MDR made up only $11.6 \%$ of the total isolates characterized (7). D. Long (personal communication) found the MDR- virulence phenotype group to comprise $22.8 \%$ of the total U.S. isolates in 1997. Consistent with our 1997 results, Long also found that $66 \%$ of the isolates he collected in Nebraska that year were of the MDR- virulence phenotype. It was also the dominant virulence phenotype in the central Great Plains at 47, 35, and $48 \%$ frequencies in Oklahoma, Kansas, and South Dakota, respectively (D. Long, personal communication). This virulence phenotype was evenly distributed in the three wheatgrowing regions in Nebraska that had leaf rust (Table 1). It is not unusual to find uniformity in virulence phenotypes from $P$. triticina collections within certain geographic areas. Kolmer (6), in 1990, noted that virulence phenotypes MFB and TBG were the two most common virulence phenotypes in collections from Manitoba and Saskatchewan.

Isolates in the T- virulence phenotype groups comprised $18 \%$ of the total $\mathrm{Ne}$ braska isolates characterized in 1997 (Table 1). In the national survey, virulence phenotype group TDR in the central Great Plains ranged from 5\% frequency in Kansas to $15 \%$ in Nebraska (D. Long, personal communication). Our 1997 survey categorized $13 \%$ of the isolates into the TDRvirulence phenotype group. The Canadian survey (7) in 1997 did not detect this virulence phenotype, and it occurred only in a very low frequency in North and South Dakota (D. Long, personal communication).
In the 1997 Nebraska survey, 14\% of the isolates were categorized as virulence phenotype PDRR, and as a whole the Pvirulence phenotype group comprised $19 \%$ of the total Nebraska isolates (Table 1). Our results for P- virulence phenotype groups in 1997 differed somewhat from those of Kolmer (7) and Long (personal communication). Long found $1 \%$ of the U.S. isolates collected in the central Great Plains to have a P- virulence phenotype, but $33 \%$ of the isolates from Missouri were characterized as virulence phenotype PLMQ. In Ontario, virulence phenotype PBLQ comprised 29.3\% of the 1997 isolates, but no P-phenotypes were found in Manitoba and Saskatchewan (7).

New virulence phenotypes were identified in 1998 in the Nebraska leaf rust population that were not identified in 1997. In 1997, fewer field isolates were collected than in 1998, which, in part, could account for fewer virulence phenotypes identified in 1997 than were identified in 1998. Consistent with 1997, MDR- was the most common virulence phenotype group in Nebraska in 1998 (Table 2), which indicates that the relative dominance in virulence phenotypes found in Nebraska differed from 1995 to 1998 (21). It accounted for $57 \%$ of the total rust isolates and ranged from $42 \%$ of the eastern population to $78 \%$ of the Panhandle population. Within the MDR- virulence phenotype group, MDRM (virulent on $L r l, 3,3 \mathrm{ka}, 10$, $11,18,23,24$, and 30) and MDRR (virulent on $L r 1,3,3 k a, 10,11,23,24$, and 30) each comprised $27 \%$ of the Nebraska rust collection. Phenotypes MDRM and MDRR differ only in the infection type produced on Lr18. MDRM is avirulent to this gene, whereas MDRR is virulent.

Virulence phenotype TDR- was found in only $3 \%$ of the 1998 Nebraska collection compared with $13 \%$ in 1997 . As a whole, the T- virulence phenotype group (virulent on $L r 1,2 a, 2 c$, and 3 ) made up only $6 \%$ of the 1998 leaf rust population compared with $18 \%$ in 1997 . This was probably due to the reduced virulence frequency in 1998 to $L r 2 a$ and $2 c$ (Table 3). Results for the Pvirulence phenotype group differed little between 1997 and 1998 at 19 and 16\%, respectively.

Virulence frequencies. Of the 1997 isolates, $61 \%$ were collected in the east, $12 \%$ in the central, $26 \%$ in the west central, and $0 \%$ in the Panhandle of Nebraska. The distribution of isolates in the 1998 leaf rust collections was $28 \%$ from the east, $40 \%$ from the central, $12 \%$ from the west central, and $20 \%$ from the Panhandle.

Table 3 summarizes the virulence frequencies from 1995 through 1998 to each of the 16 near-isogenic lines, and Table 4 summarizes the virulence frequency for 1997 and 1998 by geographic region. Consistent with earlier surveys $(20,21)$, virulence frequencies in 1997 and 1998 were high to $L r l, 3,3 k a, 10,11$, and 30. Kolmer (7) reported high virulence frequencies to $L r l, 3$, and 10 but not to $L r 3 k a$ and 30 in his 1997 survey in Canada. In the United States, D. Long (personal communication) found consistently high virulence frequencies to $\mathrm{Lrl}, 3$, and 10 since 1986. More recently, Long (10; personal communication) has found the virulence to $L r 3 k a, 11$, and 30 to be increasing, and in 1997 reported virulence frequencies of 64,72 , and $64 \%$, respectively, to $L r 3 \mathrm{ka}$, 11 , and 30 . These are lower than the virulence frequencies found in the Nebraska surveys (Table 3) but still show that the level of virulence to these three genes is relatively

Table 1. Virulence phenotypes of Puccinia triticina isolates collected in Nebraska in $1997^{\mathrm{x}}$

\begin{tabular}{|c|c|c|c|c|c|c|c|c|c|c|c|}
\hline \multirow[b]{2}{*}{$P t$ code $^{y}$} & \multirow[b]{2}{*}{ Virulence combination ${ }^{\mathrm{z}}$} & \multicolumn{2}{|c|}{ East } & \multicolumn{2}{|c|}{ Central } & \multicolumn{2}{|c|}{ West central } & \multicolumn{2}{|c|}{ Panhandle } & \multicolumn{2}{|c|}{ Total } \\
\hline & & No. & $\%$ & No. & $\%$ & No. & $\%$ & No. & $\%$ & No. & $\%$ \\
\hline MDMR & $1,3,3 \mathrm{ka}, 10,18,23,24,30$ & 0 & 0.0 & 0 & 0.0 & 1 & 3.1 & 0 & 0.0 & 1 & 0.8 \\
\hline MDRR & $1,3,3 \mathrm{ka}, 10,11,18,23,24,30$ & 40 & 54.1 & 6 & 40.0 & 15 & 46.9 & 0 & 0.0 & 61 & 50.8 \\
\hline MDTR & $1,3,3 \mathrm{ka}, 10,11,17,18,23,24,30$ & 1 & 1.4 & 1 & 6.7 & 4 & 12.5 & 0 & 0.0 & 6 & 5.0 \\
\hline MFRQ & $1,3,3 \mathrm{ka}, 10,11,18,24,26,30$ & 2 & 3.0 & 0 & 0.0 & 3 & 9.4 & 0 & 0.0 & 5 & 4.2 \\
\hline MFRR & $1,3,3 \mathrm{ka}, 10,11,18,23,24,26,30$ & 0 & 0.0 & 2 & 13.3 & 0 & 0.0 & 0 & 0.0 & 2 & 1.7 \\
\hline MFTR & $1,3,3 \mathrm{ka}, 10,11,17,18,23,24,26,30$ & 1 & 1.4 & 0 & 0.0 & 0 & 0.0 & 0 & 0.0 & 1 & 0.8 \\
\hline PBRQ & $1,2 \mathrm{c}, 3,3 \mathrm{ka}, 10,11,18,30$ & 0 & 0.0 & 0 & 0.0 & 1 & 3.1 & 0 & 0.0 & 1 & 0.8 \\
\hline PDHQ & $1,2 \mathrm{c}, 3,10,11,18,24,30$ & 1 & 1.4 & 0 & 0.0 & 0 & 0.0 & 0 & 0.0 & 1 & 0.8 \\
\hline PDKR & $1,2 \mathrm{c}, 3,10,11,17,18,23,24,30$ & 1 & 1.4 & 0 & 0.0 & 0 & 0.0 & 0 & 0.0 & 1 & 0.8 \\
\hline PDMR & $1,2 \mathrm{c}, 3,3 \mathrm{ka}, 10,18,23,24,30$ & 1 & 1.4 & 0 & 0.0 & 0 & 0.0 & 0 & 0.0 & 1 & 0.8 \\
\hline PDRR & $1,2 \mathrm{c}, 3,3 \mathrm{ka}, 10,11,18,23,24,30$ & 11 & 14.9 & 1 & 6.7 & 5 & 15.6 & 0 & 0.0 & 17 & 14.2 \\
\hline PDTR & $1,2 \mathrm{c}, 3,3 \mathrm{ka}, 10,11,17,18,23,24,30$ & 1 & 1.4 & 0 & 0.0 & 0 & 0.0 & 0 & 0.0 & 1 & 0.8 \\
\hline PFRR & $1,2 \mathrm{c}, 3,3 \mathrm{ka}, 10,11,18,23,24,26,30$ & 1 & 1.4 & 0 & 0.0 & 0 & 0.0 & 0 & 0.0 & 1 & 0.8 \\
\hline TDHR & $1,2 \mathrm{a}, 2 \mathrm{c}, 3,10,11,18,23,24,30$ & 1 & 1.4 & 0 & 0.0 & 0 & 0.0 & 0 & 0.0 & 1 & 0.8 \\
\hline TDRR & $1,2 \mathrm{a}, 2 \mathrm{c}, 3,3 \mathrm{ka}, 10,11,18,23,24,30$ & 10 & 13.5 & 4 & 26.7 & 1 & 3.1 & 0 & 0.0 & 15 & 12.5 \\
\hline TFRR & $1,2 \mathrm{a}, 2 \mathrm{c}, 3,3 \mathrm{ka}, 10,11,18,23,24,26,30$ & 3 & 4.1 & 1 & 6.7 & 1 & 3.1 & 0 & 0.0 & 5 & 4.2 \\
\hline SDRR & $1,2 \mathrm{a}, 2 \mathrm{c}, 3 \mathrm{ka}, 10,11,18,23,24,30$ & 0 & 0.0 & 0 & 0.0 & 1 & 3.1 & 0 & 0.0 & 1 & 0.8 \\
\hline Total & & 74 & & 15 & & 32 & & 0 & & 121 & \\
\hline
\end{tabular}

${ }^{\mathrm{x}}$ Number and percent isolates from indicated area.

y $P t$ code or virulence phenotype is based on high/low infection type on 16 near-isogenic lines of Thatcher wheat each with a different gene for leaf rust resistance. The 12 differentials $(\operatorname{Lrl}, 2 a, 2 c, 3,3 \mathrm{ka}, 9,11,16,17,24,26$, and 30) in the $P t$ nomenclature were used along with near-isogenic lines $L r 10$, 18,21 , and 23 .

${ }^{\mathrm{z}} \mathrm{Lr}$ genes on which the isolate is virulent. 
common throughout the United States and has reached a high level.

High frequencies of virulence in 1997 and 1998 to $L r 1,3,3 k a, 10,11,23,24$, and 30 were common across the four Nebraska wheat growing regions (Table 4). When averaged over geographic regions, low to moderate virulence frequencies in 1997 and 1998 were found for $\operatorname{Lr} 2 a, 2 c, 17$, and 26.

In 1997, 33\% of the central Nebraska isolates were virulent to $L r 2 a$, whereas only $9 \%$ of the west central isolates showed virulence to this gene. In 1998, virulence to $L r 2 a$ was highest at $12 \%$ in the eastern isolates and lowest in the Panhandle, central, and west central isolates at 0,4 , and $9 \%$, respectively. In 1997, virulence frequency to $L r 2 c$ ranged from $28 \%$ in the west central to $41 \%$ in the east, and in 1998 , it ranged from $34 \%$ in the east to
6\% in the Panhandle. Approximately 32\% of the isolates from the west central in 1998 were in virulence phenotype groups $\mathrm{P}$ - or T-, both of which show virulence to $L r 2 c$. When virulence frequency was tested for the effects of years, geographical region, and year-by-region interaction, only $\operatorname{Lr} 2 a$ and 17 had a significant year effect. None of the genes analyzed in Table 4 showed a significant region effect. This differs from that reported by Kolmer (7) and Long (9), who found that frequencies of virulence differed among collections from the various agroecological areas in Canada and the United States.

Our surveys showed that all isolates were virulent to $\operatorname{Lr} 18$ in 1997 , but in 1998 , virulence ranged from $64 \%$ in the east to $34 \%$ in the Panhandle. Avirulent pathotypes to $L r 18$ may appear virulent based on seedling tests at greenhouse temperatures that approach $25^{\circ} \mathrm{C}$ (12). Our tests were conducted at greenhouse temperatures of 20 to $25^{\circ} \mathrm{C}$, which may account for the pathogenic variation in years by geographical region with $\operatorname{Lr} 18$. Survey results published by Long et al. (9) indicated $<1 \%$ virulence to $\operatorname{Lr} 18$ in the central Great Plains from 1993 to 1995, whereas the Nebraska survey results for 1995 indicate $100 \%$ virulence to this gene. Although virulence frequencies for other $\mathrm{Lr}$ genes agree quite well for the Nebraska surveys $(20,21)$ and the surveys by Long et al. (9), the data for $\operatorname{Lrl} 8$ do not agree. This discrepancy probably results from difficulty in reading disease reactions on the Lrl8 line due to breakdown of $\operatorname{Lr} 18$ resistance at high temperatures in the Nebraska tests.

Virulence frequency to $\mathrm{Lr} 17$ in the Nebraska collection has varied since 1995

Table 2. Virulence phenotypes of Puccinia triticina isolates collected in Nebraska in $1998^{\mathrm{x}}$

\begin{tabular}{|c|c|c|c|c|c|c|c|c|c|c|c|}
\hline \multirow[b]{2}{*}{ Pt Code ${ }^{y}$} & \multirow[b]{2}{*}{ Virulence combination $^{\mathrm{z}}$} & \multicolumn{2}{|c|}{ East } & \multicolumn{2}{|c|}{ Central } & \multicolumn{2}{|c|}{ West central } & \multicolumn{2}{|c|}{ Panhandle } & \multicolumn{2}{|c|}{ Total } \\
\hline & & No. & $\%$ & No. & $\%$ & No. & $\%$ & No. & $\%$ & No. & $\%$ \\
\hline MBFR & $1,3,10,17,18,23,30$ & 1 & 2.0 & 0 & 0.0 & 0 & 0.0 & 0 & 0.0 & 1 & 0.6 \\
\hline MBFQ & $1,3,10,17,18,30$ & 0 & 0.0 & 0 & 0.0 & 0 & 0.0 & 1 & 2.9 & 1 & 0.6 \\
\hline MBKR & $1,3,10,11,17,18,23,30$ & 2 & 4.0 & 0 & 0.0 & 0 & 0.0 & 0 & 0.0 & 2 & 1.1 \\
\hline MBKM & $1,3,10,11,17,23,30$ & 0 & 0.0 & 0 & 0.0 & 1 & 4.5 & 0 & 0.0 & 1 & 0.6 \\
\hline MBPM & $1,3,3 \mathrm{ka}, 10,17,23,30$ & 1 & 2.0 & 0 & 0.0 & 0 & 0.0 & 0 & 0.0 & 1 & 0.6 \\
\hline MBRM & $1,3,3 \mathrm{ka}, 10,11,23,30$ & 0 & 0.0 & 2 & 2.8 & 0 & 0.0 & 0 & 0.0 & 2 & 1.1 \\
\hline MBRL & $1,3,3 \mathrm{ka}, 10,11,30$ & 1 & 2.0 & 1 & 1.4 & 0 & 0.0 & 0 & 0.0 & 2 & 1.1 \\
\hline MBRR & $1,3,3 \mathrm{ka}, 10,11,18,23,30$ & 0 & 0.0 & 2 & 2.8 & 1 & 4.5 & 0 & 0.0 & 3 & 1.7 \\
\hline МВТM & $1,3,3 \mathrm{ka}, 10,11,17,23,30$ & 1 & 2.0 & 1 & 1.4 & 0 & 0.0 & 2 & 5.7 & 4 & 2.2 \\
\hline MDFM & $1,3,10,17,23,24,30$ & 0 & 0.0 & 2 & 2.8 & 0 & 0.0 & 0 & 0.0 & 2 & 1.1 \\
\hline MDHQ & $1,3,10,11,18,24,30$ & 1 & 2.0 & 0 & 0.0 & 0 & 0.0 & 0 & 0.0 & 1 & 0.6 \\
\hline MDHM & $1,3,10,11,23,24,30$ & 0 & 0.0 & 0 & 0.0 & 0 & 0.0 & 1 & 2.9 & 1 & 0.6 \\
\hline MDKM & $1,3,10,11,17,23,24,30$ & 2 & 4.0 & 1 & 1.4 & 0 & 0.0 & 0 & 0.0 & 3 & 1.7 \\
\hline MDMM & $1,3,3 \mathrm{ka}, 10,23,24,30$ & 0 & 0.0 & 0 & 0.0 & 0 & 0.0 & 1 & 2.9 & 1 & 0.6 \\
\hline MDML & $1,3,3 \mathrm{ka}, 10,24,30$ & 0 & 0.0 & 0 & 0.0 & 1 & 4.5 & 0 & 0.0 & 1 & 0.6 \\
\hline MDRL & $1,3,3 \mathrm{ka}, 10,11,24,30$ & 2 & 4.0 & 1 & 1.4 & 0 & 0.0 & 1 & 2.9 & 4 & 2.2 \\
\hline MDRM & $1,3,3 \mathrm{ka}, 10,11,23,24,30$ & 5 & 10.0 & 21 & 29.6 & 7 & 31.8 & 15 & 42.9 & 48 & 27.0 \\
\hline MDRQ & $1,3,3 \mathrm{ka}, 10,11,18,24,30$ & 0 & 0.0 & 1 & 1.4 & 0 & 0.0 & 0 & 0.0 & 1 & 0.6 \\
\hline MDRR & $1,3,3 \mathrm{ka}, 10,11,18,23,24,30$ & 14 & 28.0 & 22 & 31.0 & 3 & 13.6 & 9 & 25.7 & 48 & 27.0 \\
\hline MDTM & $1,3,3 \mathrm{ka}, 10,11,17,23,24,30$ & 0 & 0.0 & 3 & 4.2 & 1 & 4.5 & 0 & 0.0 & 4 & 2.2 \\
\hline MDTR & $1,3,3 \mathrm{ka}, 10,11,17,18,23,24,30$ & 1 & 2.0 & 0 & 0.0 & 1 & 4.5 & 0 & 0.0 & 2 & 1.1 \\
\hline MFFM & $1,3,10,17,23,24,26,30$ & 0 & 0.0 & 0 & 0.0 & 0 & 0.0 & 1 & 2.9 & 1 & 0.6 \\
\hline MFRM & $1,3,3 \mathrm{ka}, 10,11,23,24,26,30$ & 1 & 2.0 & 0 & 0.0 & 0 & 0.0 & 1 & 2.9 & 2 & 1.1 \\
\hline MFRR & $1,3,3 \mathrm{ka}, 10,11,18,23,24,26,30$ & 0 & 0.0 & 0 & 0.0 & 0 & 0.0 & 1 & 2.9 & 1 & 0.6 \\
\hline MFTR & $1,3,3 \mathrm{ka}, 10,11,17,18,23,24,26,30$ & 1 & 2.0 & 1 & 1.4 & 0 & 0.0 & 0 & 0.0 & 2 & 1.1 \\
\hline PBRM & $1,2 \mathrm{c}, 3,3 \mathrm{ka}, 10,11,23,30$ & 0 & 0.0 & 2 & 2.8 & 0 & 0.0 & 0 & 0.0 & 2 & 1.1 \\
\hline PBMR & $1,2 \mathrm{c}, 3,3 \mathrm{ka}, 10,18,23,30$ & 0 & 0.0 & 0 & 0.0 & 1 & 4.5 & 0 & 0.0 & 1 & 0.6 \\
\hline PDMQ & $1,2 \mathrm{c}, 3,3 \mathrm{ka}, 10,18,24,30$ & 0 & 0.0 & 1 & 1.4 & 0 & 0.0 & 0 & 0.0 & 1 & 0.6 \\
\hline PDFR & $1,2 \mathrm{c}, 3,10,17,18,23,24,30$ & 1 & 2.0 & 0 & 0.0 & 0 & 0.0 & 0 & 0.0 & 1 & 0.6 \\
\hline PDRM & $1,2 \mathrm{c}, 3,3 \mathrm{ka}, 10,11,23,24,30$ & 2 & 4.0 & 4 & 5.6 & 2 & 9.1 & 1 & 2.9 & 9 & 5.1 \\
\hline PDRR & $1,2 \mathrm{c}, 3,3 \mathrm{ka}, 10,11,18,23,24,30$ & 5 & 10.0 & 1 & 1.4 & 1 & 4.5 & 1 & 2.9 & 8 & 4.5 \\
\hline PDTM & $1,2 \mathrm{c}, 3,3 \mathrm{ka}, 10,11,17,23,24,30$ & 1 & 2.0 & 2 & 2.8 & 0 & 0.0 & 0 & 0.0 & 3 & 1.7 \\
\hline PDTR & $1,2 \mathrm{c}, 3,3 \mathrm{ka}, 10,11,17,18,23,24,30$ & 2 & 4.0 & 0 & 0.0 & 0 & 0.0 & 0 & 0.0 & 2 & 1.1 \\
\hline PFTR & $1,2 \mathrm{c}, 3,3 \mathrm{ka}, 10,11,17,18,23,24,26,30$ & 0 & 0.0 & 0 & 0.0 & 1 & 4.5 & 0 & 0.0 & 1 & 0.6 \\
\hline TBFL & $1,2 \mathrm{a}, 2 \mathrm{c}, 3,10,17,30$ & 0 & 0.0 & 1 & 1.4 & 0 & 0.0 & 0 & 0.0 & 1 & 0.6 \\
\hline TBFQ & $1,2 \mathrm{a}, 2 \mathrm{c}, 3,10,17,18,30$ & 1 & 2.0 & 0 & 0.0 & 0 & 0.0 & 0 & 0.0 & 1 & 0.6 \\
\hline TDCM & $1,2 \mathrm{a}, 2 \mathrm{c}, 3,10,23,24,30$ & 0 & 0.0 & 1 & 1.4 & 0 & 0.0 & 0 & 0.0 & 1 & 0.6 \\
\hline TDMM & $1,2 \mathrm{a}, 2 \mathrm{c}, 3,3 \mathrm{ka}, 10,23,24,30$ & 0 & 0.0 & 1 & 1.4 & 0 & 0.0 & 0 & 0.0 & 1 & 0.6 \\
\hline TDRM & $1,2 \mathrm{a}, 2 \mathrm{c}, 3,3 \mathrm{ka}, 10,11,23,24,30$ & 1 & 2.0 & 0 & 0.0 & 2 & 9.1 & 0 & 0.0 & 3 & 1.7 \\
\hline TDRR & $1,2 \mathrm{a}, 2 \mathrm{c}, 3,3 \mathrm{ka}, 10,11,18,23,24,30$ & 2 & 4.0 & 0 & 0.0 & 0 & 0.0 & 0 & 0.0 & 2 & 1.1 \\
\hline TDTM & $1,2 \mathrm{a}, 2 \mathrm{c}, 3,3 \mathrm{ka}, 10,11,17,23,24,30$ & 1 & 2.0 & 0 & 0.0 & 0 & 0.0 & 0 & 0.0 & 1 & 0.6 \\
\hline TFTR & $1,2 \mathrm{a}, 2 \mathrm{c}, 3,3 \mathrm{ka}, 10,11,17,18,23,24,26,30$ & 1 & 2.0 & 0 & 0.0 & 0 & 0.0 & 0 & 0.0 & 1 & 0.6 \\
\hline Total & & 50 & & 71 & & 22 & & 35 & & 178 & \\
\hline
\end{tabular}

$\mathrm{x}$ Number and percent isolates from indicated area.

y $P t$ code or virulence phenotype is based on high/low infection type on 16 near-isogenic lines of Thatcher wheat each with a different gene for leaf rust resistance. The 12 differentials $(\operatorname{Lrl}, 2 a, 2 c, 3,3 \mathrm{ka}, 9,11,16,17,24,26$, and 30) in the Pt nomenclature were used along with near-isogenic lines $L r 10$, 18,21 , and 23 .

${ }^{\mathrm{z}} \mathrm{Lr}$ genes on which the isolate is virulent. 
(Table 3). It increased from 8\% in 1997 to $19 \%$ in 1998. Across the four Nebraska wheat-growing regions, virulence frequency to $\operatorname{Lrl} 17$ ranged in 1997 from a low of $5 \%$ in the east to a high of $13 \%$ in the west central, and in 1998 it ranged from a low of $11 \%$ in the Panhandle to a high of $32 \%$ in the east (Table 4). Virulence to Lrl7 was found in four phenotypes in 1997 and in 20 in 1998 (Tables 1 and 2).

Virulence frequency to $L r 24$ was above 85\% across Nebraska in 1997 and 1998 (Table 4). Virulence to Lr26 decreased from 1997 to 1998 in all regions. Virulence frequency was less than $21 \%$ in 1997 and less than $10 \%$ in 1998 (Table 4). No virulence was found to $L r 21$. McIntosh et al. (12) state that virulence to $L r 21$ has not been found in North America; however, Watkins et al. (20) and Statler et al. (18) found virulence to $\mathrm{Lr} 21$ in surveys in $\mathrm{Ne}$ braska from 1992 to 1993 and in North Dakota from 1982 to 1984 , respectively. A low infection type $(2+)$ with this gene is hard to decipher, so it is possible that avirulent responses could occasionally be interpreted as virulent based on seedling reaction (12).

As noted in Canada with $\operatorname{Lr} 9$ in 1997 (7), none of the Nebraska isolates were virulent on $\operatorname{Lr} 9$ (Tables 3 and 4). D. Long (personal communication) found a low (5\%) virulence frequency to $\operatorname{Lr} 9$ in 1997.

Virulence to Lrl6 was not found in the Nebraska collections in 1997 or 1998. This was consistent with earlier comprehensive surveys (9) in which less than $2 \%$ of the U.S. leaf rust population from 1993 to 1995 showed virulence to Lr16. In Canada, virulence to $\mathrm{Lrl6}$ increased from $6 \%$ in

Table 3. Virulence frequency ${ }^{\mathrm{y}}$ for the 1995, 1996, 1997, and 1998 Puccinia triticina populations in Nebraska to 16 near-isogenic Thatcher wheat differentials

\begin{tabular}{lrrrrrc}
\hline $\boldsymbol{L} \boldsymbol{r}$ gene & $\mathbf{1 9 9 5}$ & $\mathbf{1 9 9 6}$ & $\mathbf{1 9 9 7}$ & $\mathbf{1 9 9 8}$ & Mean & Slope b $^{\mathbf{z}}$ \\
\hline 1 & 100 & 100 & 100 & 100 & 100 & - \\
$2 a$ & 27 & 55 & 20 & 6 & 27 & $-11.6^{* \wedge}$ \\
$2 c$ & 40 & 55 & 37 & 23 & 39 & $-8.6^{* \wedge}$ \\
3 & 100 & 100 & 100 & 100 & 100 & - \\
$3 k a$ & 93 & 85 & 99 & 91 & 92 & $\wedge$ \\
9 & 0 & 9 & 0 & 0 & 2 & - \\
10 & 100 & 100 & 100 & 100 & 100 & - \\
11 & 96 & 97 & 99 & 92 & 96 & - \\
16 & 0 & 4 & 0 & 0 & 1 & - \\
17 & 0 & 30 & 8 & 19 & 14 & $6.3^{* \wedge}$ \\
18 & 100 & 94 & 100 & 43 & 84 & $-1.2^{* \wedge}$ \\
21 & $\ldots$ & $\ldots$ & 0 & 0 & 0 & - \\
23 & $\ldots$ & $\ldots$ & 95 & 93 & 94 & $\mathrm{~ns}$ \\
24 & 58 & 34 & 99 & 88 & 70 & $15.4^{* \wedge}$ \\
26 & 14 & 1 & 14 & 5 & 9 & $\wedge$ \\
30 & 100 & 96 & 100 & 100 & 99 & - \\
Total no. & 120 & 156 & 121 & 178 & & \\
\hline
\end{tabular}

${ }^{\mathrm{y}}$ Represents the percentage of leaf rust isolates collected from that year.

${ }^{\mathrm{z}} \mathrm{b}=$ regression slope over years, $\mathrm{ns}=$ not significant. $*=$ significant $(P<0.05)$ linear trend, ${ }^{\wedge}=$ significant $(P<0.05)$ residual trend, and $-=$ not statistically analyzed since more than $25 \%$ of cells had counts less than $5(1)$.

1996 to $16 \%$ in 1997 in Manitoba and Saskatchewan (7). This gene provides an intermediate level of protection, as demonstrated by the low infection types ranging from 1 to $3 \mathrm{C}$ (12). Although McIntosh et al. (12) indicate that the low infection types for $L r 16$ range from 1 to $3 \mathrm{C}$, we consider a $3 \mathrm{C}$ as a high infection type in our ratings. The hard red winter wheat cultivars Arapahoe, Redland, and Vista, which contain Lrl6 along with at least one other leaf rust resistance gene (14), comprised 30 to $36 \%$ of the Nebraska wheat acreage in 1997 and 1998. Although Lrl6 continues to provide good resistance to the North American leaf rust population, severities on cultivars with Lr16 may increase in future years if these cultivars become commonly grown in the Great Plains.

When virulence frequency was regressed over years (Table 3), there were significant linear trends over years in virulence frequencies for $L r 2 a, 2 c, 17,18$, and 24 (Table 3). Virulence frequency to $\operatorname{Lr} 2 a$ and $2 c$ increased from 1995 to 1996 and then decreased from 1996 to 1998 . Overall, the virulence frequency to $\operatorname{Lr} 2 a, 2 c$, and 18 showed a significant decreasing linear trend over years with a significant deviation around the linear trend due to variation from year to year (Table 3). Virulence frequency to Lr3ka did not show a significant linear trend but had highly significant $(P<0.01)$ variation in virulence frequency from year to year (Table 3 ). Virulence to Lr17 and 24 showed a significant increasing linear trend over years, but the most dramatic change in virulence frequency occurred with Lr24, which increased $15.4 \%$ per year $(P<0.05)$ on average. The year-to-year variation around the linear trend for $L r 24$ was also significant. The virulence frequency to $L r 26$ did not show a significant linear trend over years but was

Table 4. Virulence frequency ${ }^{\mathrm{x}}$ of the 1997 and 1998 Puccinia triticina population in Nebraska by geographic region to 16 near-isogenic Thatcher wheat lines

\begin{tabular}{|c|c|c|c|c|c|c|c|c|c|c|c|}
\hline \multirow[b]{2}{*}{$L r$ gene } & \multicolumn{2}{|c|}{ East } & \multicolumn{2}{|c|}{ Central } & \multicolumn{2}{|c|}{ West central } & \multicolumn{2}{|c|}{ Panhandle $^{\mathrm{y}}$} & \multicolumn{2}{|c|}{ Mean } & \multirow{2}{*}{$\begin{array}{c}\text { Year and } \\
\text { region effects }\end{array}$} \\
\hline & 1997 & 1998 & 1997 & 1998 & 1997 & 1998 & 1997 & 1998 & 1997 & 1998 & \\
\hline 1 & 100 & 100 & 100 & 100 & 100 & 100 & $\ldots$ & 100 & 100 & 100 & - \\
\hline $2 a$ & 19 & 12 & 33 & 4 & 9 & 9 & $\ldots$ & 0 & 20 & 6 & $\mathrm{Z}$ \\
\hline $2 c$ & 41 & 34 & 40 & 18 & 28 & 32 & $\ldots$ & 6 & 37 & 23 & ns \\
\hline 3 & 100 & 100 & 100 & 100 & 100 & 100 & $\ldots$ & 100 & 100 & 100 & - \\
\hline $3 k a$ & 96 & 84 & 100 & 93 & 100 & 95 & $\ldots$ & 91 & 99 & 91 & - \\
\hline 9 & 0 & 0 & 0 & 0 & 0 & 0 & $\ldots$ & 0 & 0 & 0 & - \\
\hline 10 & 100 & 100 & 100 & 100 & 100 & 100 & $\ldots$ & 100 & 100 & 100 & - \\
\hline 11 & 99 & 92 & 100 & 92 & 97 & 91 & $\ldots$ & 91 & 99 & 92 & ns \\
\hline 16 & 0 & 0 & 0 & 0 & 0 & 0 & $\ldots$ & 0 & 0 & 0 & - \\
\hline 17 & 5 & 32 & 7 & 15 & 13 & 18 & $\ldots$ & 11 & 8 & 19 & $\mathrm{z}$ \\
\hline 18 & 100 & 64 & 100 & 39 & 100 & 36 & $\ldots$ & 34 & 100 & 43 & - \\
\hline 21 & 0 & 0 & 0 & 0 & 0 & 0 & $\ldots$ & 0 & 0 & 0 & - \\
\hline 23 & 96 & 90 & 100 & 93 & 88 & 95 & $\ldots$ & 94 & 95 & 93 & ns \\
\hline 24 & 100 & 86 & 100 & 87 & 97 & 86 & $\ldots$ & 91 & 99 & 88 & - \\
\hline 26 & 9 & 6 & 20 & 1 & 13 & 5 & $\ldots$ & 9 & 14 & 5 & - \\
\hline 30 & 100 & 100 & 100 & 100 & 100 & 100 & $\ldots$ & 100 & 100 & 100 & - \\
\hline Total no. & 74 & 50 & 15 & 71 & 32 & 22 & 0 & 35 & 121 & 178 & \\
\hline
\end{tabular}

${ }^{\mathrm{x}}$ Represents the percentage of leaf rust isolates collected from that specific region.

y Leaf rust was not detected in the Nebraska Panhandle in 1997.

${ }^{\mathrm{z}} \mathrm{z}=$ significant year effects $(P<0.05)$ and $-=$ not statistically analyzed since more than $25 \%$ of the cells had counts less than 5 (19). 
significant in its variation from year to year.

The Nebraska wheat leaf rust survey characterized virulence phenotypes in 1998 that were not present in 1997. It showed that during these years, the Nebraska leaf rust population had a wide range of virulence to the 16 near-isogenic differential host lines and that virulence to certain $\mathrm{Lr}$ host lines differed among the collections from the four Nebraska wheat-growing regions. There have been major shifts in virulence phenotypes and in virulence frequencies since the initial 1992 (20) Nebraska leaf rust survey. These shifts in virulence in the Nebraska leaf rust population probably reflect the increased or decreased use of certain $L r$ genes such as $L r 24$ and 26 in winter wheat cultivars grown in the southern and central Great Plains.

\section{ACKNOWLEDGMENTS}

We thank Debbie Pederson for technical assistance in the preparation of this manuscript, and James Steadman, Gary Yuen, and David Long for reviewing this manuscript. We thank the Nebraska Wheat Board for their support for our wheat disease program.

\section{LITERATURE CITED}

1. Agresti, A. 1990. Categorical Data Analysis. John Wiley \& Sons, New York. pp. 233, 249250.

2. Anikister, Y., Bushnell, W. R., Eilam, T., Manisterski, J., and Roelfs, A. P. 1997. Puc- cinia recondita causing leaf rust on cultivated wheats, wild wheats, and rye. Can. J. Bot. 75:2082-2096.

3. Dyck, P. L., and Samborski, D. J. 1968. Genetics of resistance to leaf rust in the common wheat varieties Webster, Loros, Brevit, Carina, Malakof, and Centenario. Can. J. Genet. Cytol. 10:7-17.

4. Johnson, C. O., and Mains, E. B. 1932. Studies on physiologic specialization in Puccinia triticina. U.S. Dep. Agric. Tech. Bull. 313.

5. Kolmer, J. A. 1989. Virulence and race dynamics of Puccinia recondita $\mathrm{f}$. sp. tritici in Canada during 1956-1987. Phytopathology 79:349-356.

6. Kolmer, J. A. 1992. Diversity of virulence phenotypes and effect of host sampling between and within populations of Puccinia recondita f. sp. tritici in Canada. Plant Dis. 76:618-621.

7. Kolmer, J. A. 1999. Physiologic specialization of Puccinia triticina in Canada in 1997. Plant Dis. 83:194-197.

8. Long, D. L., and Kolmer, J. A. 1989. A North American system of nomenclature for $\mathrm{Puc}$ cinia recondita $\mathrm{f}$. $\mathrm{sp}$. tritici. Phytopathology 79:525-529.

9. Long, D. L., Leonard, K. J., and Roberts, J. J. 1998. Virulence and diversity of wheat leaf rust in the United States in 1993 to 1995. Plant Dis. 82:1391-1400.

10. Mains, E. B., and Jackson, H. S. 1926. Physiologic specialization in the leaf rust of wheat, Puccinia triticina Eriks. Phytopathology 16:89-120.

11. Marshall, D. 1992. Virulence of Puccinia recondita in Texas from 1988 to 1990 . Plant Dis. 76:296-299.

12. McIntosh, R. A., Wellings, C. R., and Park, R.
F. 1995. The genes for resistance to leaf rust in wheat and triticale. Pages 29-82 in: Wheat Rusts An Atlas of Resistance Genes. Kluwer Academic Publishers, Boston.

13. McVey, D. V., and Hamilton, K. 1985. Occurrence and virulence of Puccinia recondita in Minnesota in 1982 and 1983. Plant Dis. 69:404-405.

14. McVey, D. V., and Long, D. L. 1993. Genes for leaf rust resistance in hard red winter wheat cultivars and parental lines. Crop Sci. 33:1373-1381.

15. Milus, E. A., and Line, R. F. 1980. Virulence of Puccinia recondita in the Pacific Northwest. Plant Dis. 64:78-80.

16. Niewoehner, A. S., and Leath, S. 1998. Virulence of Blumeria graminis f. sp. tritici on winter wheat in the eastern United States. Plant Dis. 82:64-68.

17. Singh, R. P. 1991. Pathogenicity variations of Puccinia recondita f. sp. tritici and $P$. graminis f. sp. tritici in wheat-growing areas of Mexico during 1988 and 1989. Plant Dis. 75:790-794.

18. Statler, G. D., Miller, J. D., and Hirsch, D. C. 1985. Wheat leaf rust in North Dakota during 1982-1984. Plant Dis. 69:720-721.

19. Steel, R. G., and Torrie, J. H. 1980. Principles and Procedures of Statistics. McGraw-Hill, New York. p. 514.

20. Watkins, J. E., Rutledge, S. S., and Baenziger, P. S. 1995. Virulence patterns of Puccinia recondita f. sp. tritici in Nebraska during 1992 and 1993. Plant Dis. 79:467-470.

21. Watkins, J. E., Rutledge, S. S., Baenziger, P. S., and Youngquist, W. 1998. Physiologic specialization of Puccinia recondita f. sp. tritici in Nebraska during 1995 and 1996. Plant Dis. 82:679-682. 